\title{
Parametric Optimization and Strength Analysis of Hard Faced Mild Steel Components Prepared by Oxy-Acetylene Gas Welding Process
}

\author{
Mahesh Kumar ${ }^{1}$, Asst. Prof. Digamber Benne ${ }^{2}$ \\ PG Student, Mechanical Engineering (CIM), GND Engineering College, Bidar, India ${ }^{1}$ \\ Assistant Professor, Mechanical Engineering, GND Engineering College, Bidar, India ${ }^{2}$
}

\begin{abstract}
Hard facing is a process of depositing a layer of material on the base metal or substrate either to develop the surface features like corrosion resistance, Hardness, Toughness \& Strength of the material etc. or to get the required size of dimension or to repair worn out products. Taguchi technique is applied for the optimization. Oxy-Acetylene gas welding process and Mild Steel material is used for hard facing. In this project a detailed experimentation is done in which the Electrode speed is primary component which impact both bead width and depth of penetration \& the Hard Faced specimen absorbs more energy than that of the specimen before hard facing and Hard Faced material is $114 \mathrm{BHN}$ harder than the normal gentle steel and Micro-Structural test shows the specimen before hard facing, uniform structure pattern of light Ferrite and dark Paralyte and after Hard Facing shows the structure pattern of Temper Marten site.
\end{abstract}

Keywords: Hard Facing, Oxy-Acetylene Gas welding, Taguchi technique, impact test, hardness, Micro-structural test.

\section{INTRODUCTION}

Hard facing is defined as the hard material is deposited over a soft material or ductile material to enhance the Hardness and Strength of the material. When the layer of material deposited for corrosion resistance then the process is known as cladding. And sometimes the parts which are damaged are built up to the required size so that they can be put back into service. Hard facing is one of the most helpful and economical ways to advance the performance of components submitted to severe Hardness \& wear condition. Hard facing is commonly in use method to advance the surface properties of farming tools, components for mining operation ; soil preparation equipment's \& earth moving equipment. An alloy is homogeneously deposited int0 the surface of an s0ft material (usually low or medium carbon steels) by welding with the purpose of increasing the hardness with0ut considerable loss in ductility and toughness of the substrate . It is estimated that more than $30 \%$ of wear \& corrosion related cost can be reduced by developing and using better techniques of controlling wear and corrosion.

The Hardness, wear and corrosion related problems can be minimized mainly by two method and are By using expensive wear and corrosion resistant alloys better than the Existing low cost ones and By improving the hardness, wear and corr0sion resistance of the existing metals and alloys by applying certain modifications to the surface .

\section{Work Material:}

The mild steel (E250 Grade-BR) having the size of $200 \mathrm{~mm} \times 100 \mathrm{~mm} \times 10 \mathrm{~mm}(\mathrm{~L} \times \mathrm{B} \times \mathrm{T})$ is utilized for the experimentation with the electrode and for Hard Facing the work material. Material since it has loads of favourable circumstances such as it has more predictable hardness, Wear Resistance and expanded elasticity and the electrode which is chosen for the specimen is ER70S-6. In which ER stands for filler electrode and 70 stands for weld strength in Mild steel, weld has lowest of 70,000 pound tensile strength / square inch of weld. And S - solid rod and 6 shows the quantity of cleaner added to the wire to maximise the weld quality.

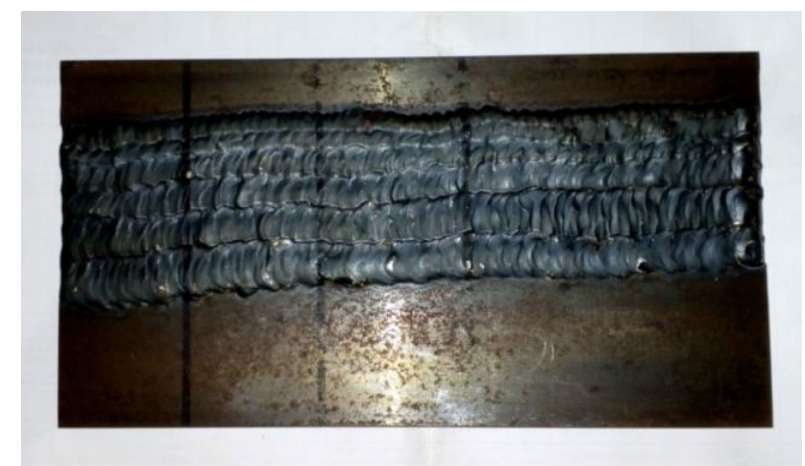

Fig 1.1 Hard Faced work piece photo

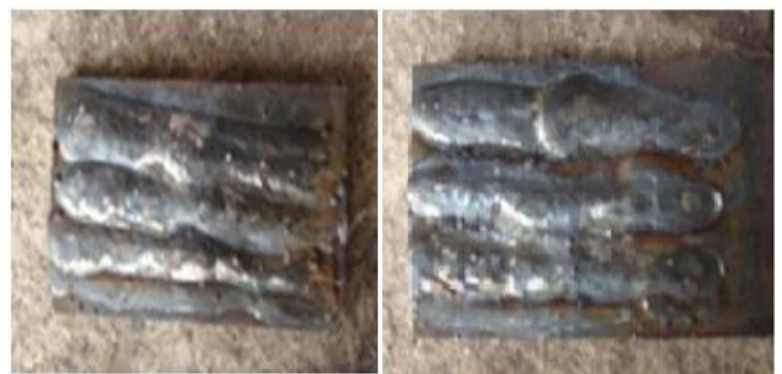

Fig 1.2 Cutting Sections of the Hard Faced Plates 


\section{EXPERIMENTAL SET UP}

The following tests were conducted in research work;

$>$ Impact Test

$>$ Brinell Hardness Test

$>$ Micro-Structural Test

The experimental plan according to L9 array and the responses of Bead width \& Depth of penetration is shown in table number 1:

Table No.1: Experimental Plan.

\begin{tabular}{|c|c|c|c|c|c|}
\hline $\begin{array}{c}\text { SL } \\
\text { No } \\
\text {. }\end{array}$ & $\begin{array}{c}\text { Gas } \\
\text { Pressure } \\
\text { (psi) }\end{array}$ & $\begin{array}{c}\text { Welding } \\
\text { Speed } \\
(\mathrm{mm} / \mathrm{mi} \\
\mathrm{n})\end{array}$ & $\begin{array}{c}\text { Electrod } \\
\text { e Speed } \\
(\mathrm{mm} / \mathrm{mi} \\
\mathrm{n})\end{array}$ & $\begin{array}{c}\text { Bead } \\
\text { Width } \\
(\mathrm{mm})\end{array}$ & $\begin{array}{c}\text { Depth of } \\
\text { Penetrat } \\
\text { ion } \\
(\mathrm{mm})\end{array}$ \\
\hline 1 & 300 & 33 & 300 & 3.39 & 2.12 \\
\hline 2 & 300 & 36 & 400 & 4.36 & 2.62 \\
\hline 3 & 300 & 39 & 500 & 5.27 & 3.61 \\
\hline 4 & 340 & 33 & 400 & 3.13 & 3.21 \\
\hline 5 & 340 & 36 & 500 & 4.33 & 3.41 \\
\hline 6 & 340 & 39 & 300 & 2.25 & 2.25 \\
\hline 7 & 380 & 33 & 500 & 3.67 & 3.09 \\
\hline 8 & 380 & 36 & 300 & 2.69 & 2.31 \\
\hline 9 & 380 & 39 & 400 & 2.39 & 2.82 \\
\hline
\end{tabular}

\section{EXPERIMENTATION \& CALCULATIONS}

\subsection{CHARPY TEST:}

The chosen work piece having the size of $200 \mathrm{~mm} \times 100 \mathrm{~mm}$ $(\mathrm{L} * \mathrm{~B})$. To test the vitality consumed by the material.

Table 2 Energy absorbed by Mild Steel before Hard Facing

\begin{tabular}{|c|c|c|c|}
\hline $\begin{array}{c}\text { Sl } \\
\text { No. }\end{array}$ & $\begin{array}{c}\text { Initial } \\
\text { Reading } \\
(\mathrm{Kg}-\mathrm{m})\end{array}$ & $\begin{array}{c}\text { Final } \\
\text { Reading } \\
(\mathrm{Kg}-\mathrm{m})\end{array}$ & $\begin{array}{c}\text { Energy absorbed } \\
(\mathrm{Kg}-\mathrm{m}) \text { (I.R.-F.R) }\end{array}$ \\
\hline 1 & 25.90 & 24.60 & 1.3 \\
\hline
\end{tabular}

Calculation:

1] Energy Absorbed = Initial weight - Final weight $=25.90-24.60=1.3 \mathrm{Kg}-\mathrm{m}$

Table No. 3 Experimental Values of Hard Faced Samples

\begin{tabular}{|c|c|c|c|}
\hline $\begin{array}{c}\text { Sl } \\
\text { No. }\end{array}$ & $\begin{array}{c}\text { Initial } \\
\text { Reading } \\
\text { (Kg-m) }\end{array}$ & $\begin{array}{c}\text { Final } \\
\text { Reading } \\
\text { (Kg-m) }\end{array}$ & $\begin{array}{c}\text { Energy absorbed } \\
\text { (Kg-m) } \\
\text { (I.R.-F.R.) }\end{array}$ \\
\hline 1 & 25.90 & 22.00 & 3.9 \\
\hline
\end{tabular}

\begin{tabular}{|l|l|l|l|}
\hline 2 & 25.90 & 23.20 & 2.7 \\
\hline 3 & 25.90 & 21.30 & 4.6 \\
\hline 4 & 25.90 & 23.10 & 2.8 \\
\hline 5 & 25.90 & 22.60 & 3.3 \\
\hline 6 & 25.90 & 21.80 & 4.1 \\
\hline 7 & 25.90 & 24.30 & 1.6 \\
\hline 8 & 25.90 & 22.20 & 3.7 \\
\hline 9 & 25.90 & 22.60 & 3.3 \\
\hline
\end{tabular}

Calculations:

1. $\quad$ Energy absorbed = I.R. - F.R.

$$
=25.90-22.00=3.90 \mathrm{Kg}-\mathrm{m}
$$

2. $\quad$ Energy absorbed $=$ I.R. - F.R. $=25.90-23.20=2.70 \mathrm{Kg}-\mathrm{m}$

\subsection{BRINELL HARDNESS TEST:}

Formula for Calculations:

Where,

$$
B H N=\frac{P}{\pi\left(\frac{D}{2}\right)\left[D-\left(\sqrt{D^{2}-d^{2}}\right)\right]}
$$

$\mathrm{P}=\operatorname{Load}(\mathrm{Kg})$

$\mathrm{D}=$ Width of Bar enter $(2.5 \mathrm{~mm})$

$\mathrm{d}=$ Diameter of Indentation $(\mathrm{mm})$

$\mathrm{t}=$ Time in seconds $(10 \mathrm{sec})$

Table 4 Hardness of work piece before Hard Facing

\begin{tabular}{|c|c|c|c|c|c|c|}
\hline $\begin{array}{c}\text { Sl } \\
\text { No. }\end{array}$ & $\begin{array}{c}\text { Material } \\
\text { Used }\end{array}$ & $\begin{array}{c}\text { Dia. of } \\
\text { Bar } \\
\text { Penetrate } \\
(\mathrm{D})(\mathrm{mm})\end{array}$ & $\begin{array}{c}\text { Load } \\
(\mathrm{Kg})\end{array}$ & $\begin{array}{c}\text { Time } \\
(\mathrm{t}) \\
(\mathrm{sec})\end{array}$ & $\begin{array}{c}\text { Dir. Of } \\
\text { Indentation } \\
(\mathrm{d})(\mathrm{mm})\end{array}$ & BHN \\
\hline 1 & $\begin{array}{c}\text { Mild } \\
\text { Steel }\end{array}$ & 2.5 & 187.50 & $10 \mathrm{sec}$ & 1.15 & 170.39 \\
\hline
\end{tabular}

Calculations:

1] $B H N=\frac{187.5}{3.927[2.5-(\sqrt{6.25-1.3225})]}=170.39$

\begin{tabular}{|cc|c|cc|c|c|}
\hline $\begin{array}{c}\text { S1 } \\
\text { No. }\end{array}$ & $\begin{array}{c}\text { Material } \\
\text { Used }\end{array}$ & $\begin{array}{c}\text { Dia. Of } \\
\text { Bar } \\
\text { penetrate } \\
(\mathbf{D})(\mathbf{m m})\end{array}$ & $\begin{array}{c}\text { Load } \\
\mathbf{K g})\end{array}$ & $\begin{array}{c}\text { T ime } \\
\mathbf{( t )} \\
\mathbf{( S e c})\end{array}$ & $\begin{array}{c}\text { Dia. Of } \\
\text { Indenta } \\
\mathbf{( d )}(\mathbf{m m})\end{array}$ & $\mathbf{B H N}$ \\
\hline 1 & $\begin{array}{c}\text { Mild } \\
\text { Steel }\end{array}$ & 2.5 & 187.50 & $\begin{array}{c}10 \\
\mathrm{sec}\end{array}$ & 1.1 & 187.23 \\
\hline 2 & $\begin{array}{c}\text { Mild } \\
\text { Steel }\end{array}$ & 2.5 & 187.50 & $\begin{array}{c}10 \\
\mathrm{sec}\end{array}$ & 1.05 & 206.52 \\
\hline 3 & $\begin{array}{c}\text { Mild } \\
\text { Steel }\end{array}$ & 2.5 & 187.50 & $\begin{array}{c}10 \\
\mathrm{sec}\end{array}$ & 0.95 & 254.60 \\
\hline 4 & $\begin{array}{l}\text { Mild } \\
\text { Steel }\end{array}$ & 2.5 & 187.50 & $\begin{array}{c}10 \\
\mathrm{sec}\end{array}$ & 1 & 228.76 \\
\hline 5 & $\begin{array}{l}\text { Mild } \\
\text { Steel }\end{array}$ & 2.5 & 187.50 & $\begin{array}{c}10 \\
\mathrm{sec}\end{array}$ & 1.1 & 187.23 \\
\hline 6 & $\begin{array}{l}\text { Mild } \\
\text { Steel }\end{array}$ & 2.5 & 187.50 & $\begin{array}{c}10 \\
\mathrm{sec}\end{array}$ & 0.95 & 254.60 \\
\hline 7 & $\begin{array}{l}\text { Mild } \\
\text { Steel }\end{array}$ & 2.5 & 187.50 & $\begin{array}{c}10 \\
\mathrm{sec}\end{array}$ & 0.9 & 284.85 \\
\hline 8 & $\begin{array}{l}\text { Mild } \\
\text { Steel }\end{array}$ & 2.5 & 187.50 & $\begin{array}{c}10 \\
\mathrm{sec}\end{array}$ & 1 & 228.76 \\
\hline 9 & $\begin{array}{l}\text { Mild } \\
\text { Steel }\end{array}$ & 2.5 & 187.50 & $\begin{array}{c}10 \\
\mathrm{sec}\end{array}$ & 1.1 & 187.23 \\
\hline
\end{tabular}

Table 5 Experimental Values of Hard Faced Samples 


\section{Calculations:}

$\begin{array}{ll}\text { 1] } B H N=\frac{187.5}{3.927[2.5-(\sqrt{6.25-1.21})]} & =187.23 \\ \text { 2] } B H N=\frac{187.5}{3.927[2.5-(\sqrt{6.25-1.1025})]} & =206.52\end{array}$

\subsection{MICRO-STRUCTURAL ANALYSIS:}

Micro-Structure of the hard faced work samples was done. It is clear from the structure that the normal sample shows the uniform structure pattern of light Ferrite and dark Paralyte before Hard Facing and has the grain size 4.5 and Hard Faced samples shows the structure pattern of Temper Marten site. The samples 2, 3, 4, 5, 6, 8 and 9 has the grain size 6.5 and the grain size of 1 st sample is 6 and the sample 7 has the higher grain size value of 7 . The Hard faced micro-structures of the samples are shown below
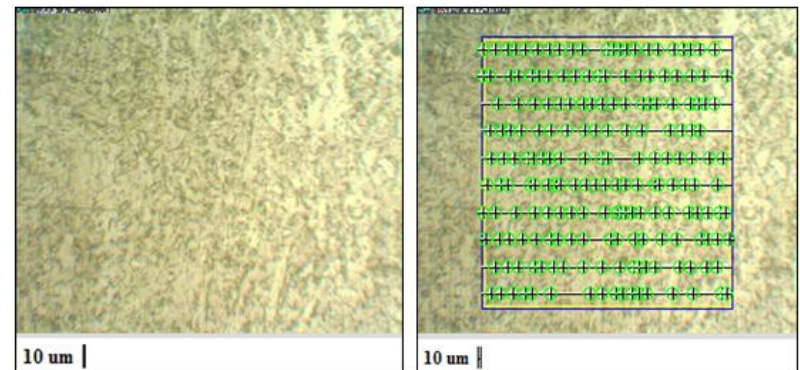

Fig 3.1 Hard Faced Sample 1

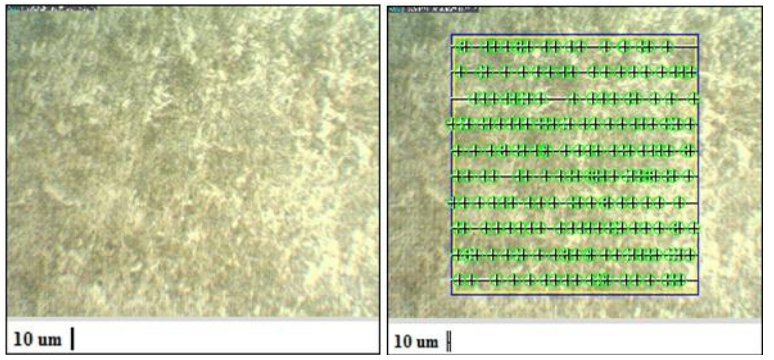

Fig 3.2 Hard Faced Sample 2

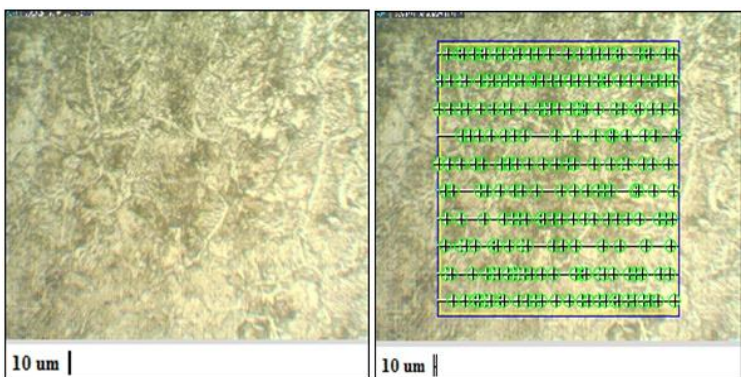

Fig 3.3 Hard Faced Sample 3

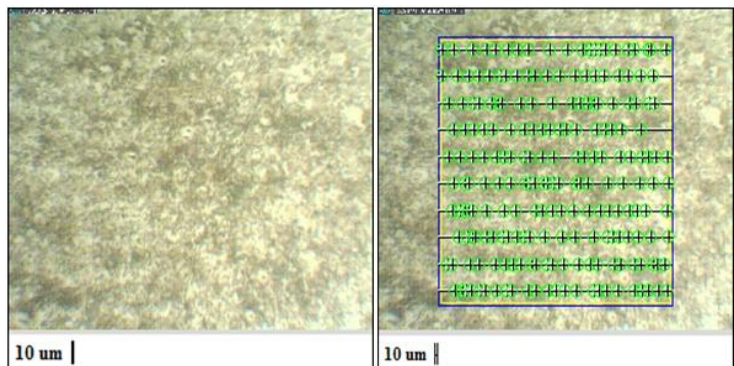

Fig 3.4 Hard Faced Sample 4

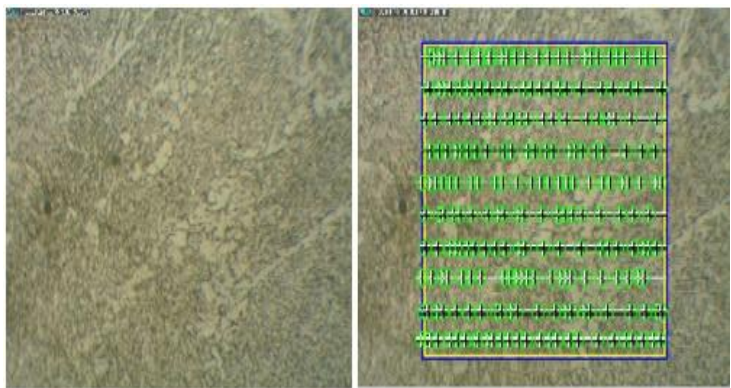

Fig 3.5 Hard Faced Sample 5

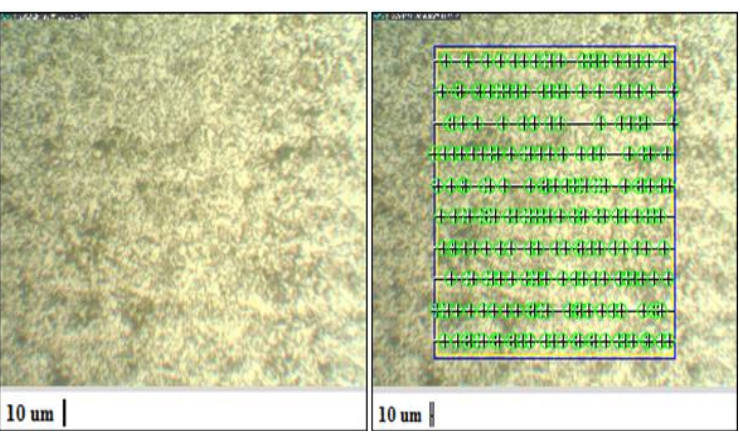

Fig 3.6 Hard Faced Sample 6

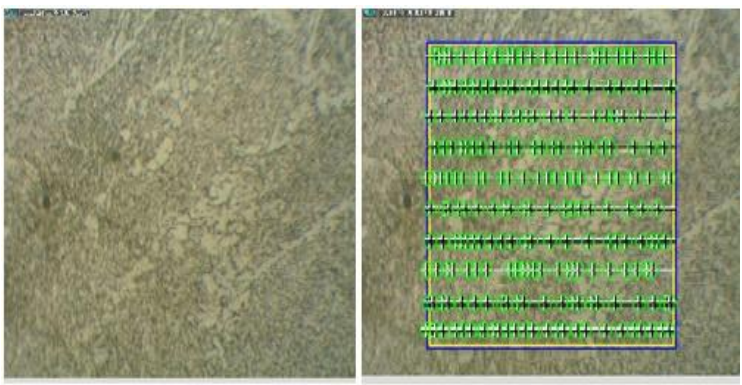

Fig 3.7 Hard Faced Sample 7

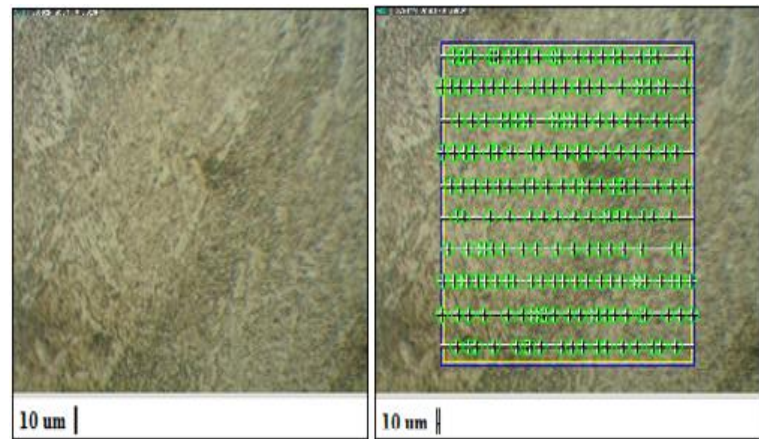

Fig 3.8 Hard Faced Sample 8

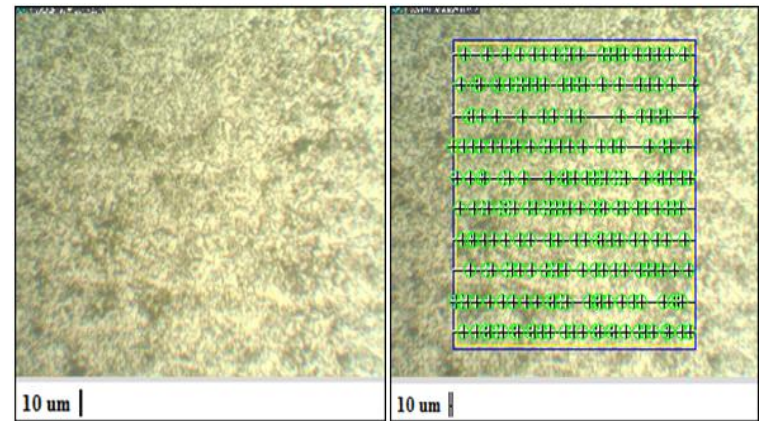

Fig 3.9 Hard Faced Sample 9 


\section{RESULT \& DISCUSSION}

\subsection{BEAD WIDTH:}

Fig 4.1 shows the main effect plot for bead width in which it shows the effects of parameter on bead width individually. The optimum range of parameters which effect on bead width are gas pressure at 300psi, welding speed at $36 \mathrm{~mm} / \mathrm{min}$ and electrode speed at $500 \mathrm{~mm} / \mathrm{min}$.

The plot shows that as the gas pressure increases the bead width decreases gradually. The bead width is increases from welding speed 33 to 36 and it decreases from 36 to 39 , the welding speed effect is very less as compared to Gas pressure and Electrode speed. And the bead width is higher at electrode speed of $500 \mathrm{~mm} / \mathrm{min}$ and it gradually decrease as decreasing the electrode speed and from the responses it has concluded that the electrode speed is affecting more on bead width followed by gas pressure and welding speed.

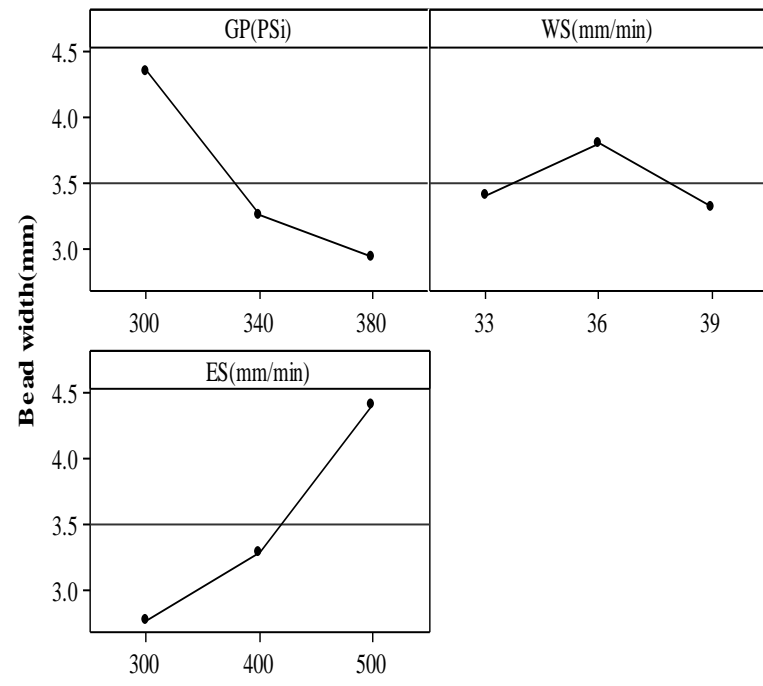

Fig 4.1 Main effects plot of Bead width

\subsection{DEPTH OF PENETRATION:}

Fig 4.2 shows the main effect plot for depth of penetration in which it shows the effects of parameter on depth of penetration individually. The optimum range of parameters which effect on depth of penetration are gas pressure at $340 \mathrm{psi}$, welding speed at $39 \mathrm{~mm} / \mathrm{min}$ and electrode speed at $500 \mathrm{~mm} / \mathrm{min}$.

The plot shows that the depth of penetration at gas pressure of 300psi to 340psi increases and from 340psi to 380 psi decrease gradually. The depth of penetration is decreases from welding speed $33 \mathrm{~mm} / \mathrm{min}$ to $36 \mathrm{~mm} / \mathrm{min}$ partially and it gradually increases from $36 \mathrm{~mm} / \mathrm{min}$ to $39 \mathrm{~mm} / \mathrm{min}$, the welding speed effect is very less as compared to Gas pressure and Electrode speed. And the depth of penetration is higher at electrode speed of $500 \mathrm{~mm} / \mathrm{min}$ and it gradually decrease as decreasing the electrode speed. And from the responses it has concluded that the electrode speed is affecting more on depth of penetration followed by gas pressure and welding speed.

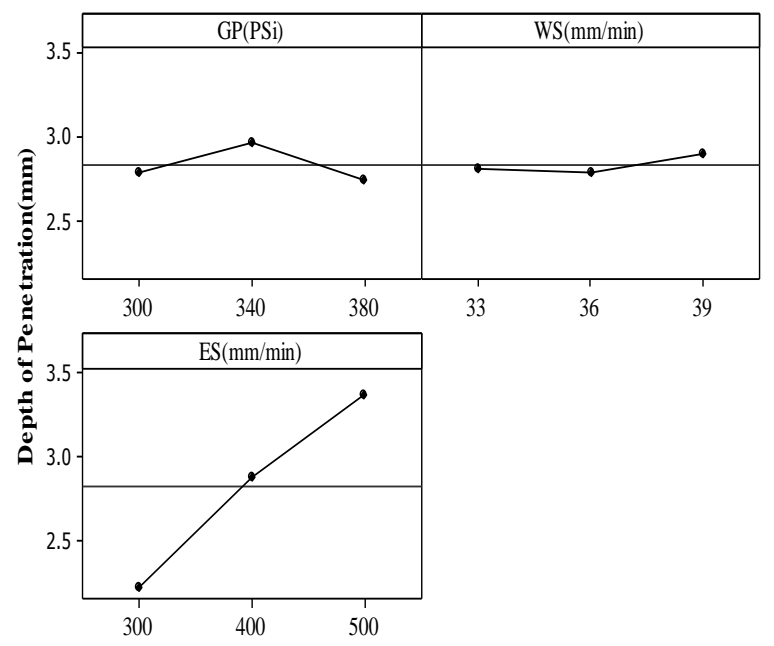

Fig 4.2 Main effects plot of Depth of Penetration

\subsection{CHARPY TEST:}

We can see that the sample before hard facing absorbs the energy of $1.3 \mathrm{Kg}-\mathrm{m}$ and Hard Faced steel after analysis which absorbs the energy of $4.6 \mathrm{Kg}-\mathrm{m}$. The difference of energy absorbed between the normal material before hard facing and after hard facing (better value) material is 1.3 $4.6=3.3 \mathrm{Kg}-\mathrm{m}$. Hence we can say that the hard faced material is $3.3 \mathrm{Kg}-\mathrm{m}$ more grounded than the normal material at trial 3. In the results we can see that the minimum energy absorbed after hard facing is $1.6 \mathrm{Kg}-\mathrm{m}$ at the trial 7 and the maximum energy absorbed after hard facing is $4.6 \mathrm{Kg}-\mathrm{m}$ at the trial 3 .

\subsection{BRINNEL HARDNESS TEST:}

The hardness value of the specimen after hard facing varied from $187.23-284.85 \mathrm{BHN}$. When we get the worth for gentle normal mild steel we get the quality of hardness is $170.39 \mathrm{BHN}$ and we get after hard facing of the specimens, the better value of hardness is $284.85 \mathrm{BHN}$ at trial 7. The difference between without hard faced material and with hard faced material, the hardness value is 170.39 $-284.85=114.46$ BHN. And, in the results we can observe that the minimum hardness value $187.23 \mathrm{BHN}$ at the trials 1,5 and 9. And the maximum hardness value $284.85 \mathrm{BHN}$ at the trial 7 of the hard faced sample.

\subsection{MICRO-STRUCTURAL ANALYSIS:}

The normal sample shows the uniform structure pattern of light Ferrite and dark Paralyte before Hard Facing which has the grain size 4.5 and The Hard Faced samples shows the structure pattern of Temper Marten site and The samples 2, 3, 4, 5, 6, 8 and 9 has the grain size 6.5 and the grain size of 1 st sample is 6 and the sample 7 has the higher grain size value of 7 .

\section{CONCLUSION}

The experimentation and hard facing of specimen are studied which shows the effect of factors on bead width, hardness, depth of penetration and toughness. From research the following conclusions are made as below 
- Electrode speed is most effecting factor compared to bead width and depth of penetration.

- According to Charpy test, the Hard Faced specimen absorbs more energy than that of the specimen before hard facing.

- According to the Brinell Hardness Test, the Hard Faced material is $114 \mathrm{BHN}$ harder than the normal gentle steel.

- According to Micro-Structural test, the specimen before hard facing shows the uniform structure pattern of light Ferrite and dark Paralyte. And after Hard Facing the specimen shows the structure pattern of Temper Marten site. And the trial 7 sample has the greater grain size value 7 .

- The project is carried out studying the hardness, toughness, wear characterization, as the basic aim of hard facing is to maximise the life of various parts used across the industry which needs high cost for replacement of original part and in this project, it has been concluded that we can progress the life of the components by Hard Facing process.

\section{REFERENCES}

[1] Er. Brij Bhushan, Dr. Abhishek Kamboj and Mr.Vikas Kambo "The Effects of Welding Processes on Microstructure and Abrasive Wear Resistance for Hard facing Deposits" Bonfring International Journal of Industrial Engineering and Management Science, Vol. 2, No. 2, June 2012. [1]

[2] Anand Sagar And Dr.G.K.Purohit "Some Studies on Mig Hard facing Of Mild Steel Components" International Journal of Engineering Research and Development, Volume 4, Issue 8 (November 2012). [2]

[3] G.R.C. Pradeep, Dr. A. Ramesh \& Dr. B. Durga Prasad "Comparative Study of Hard facing of AISI 1020 Steel by Gas Welding and Tig Welding Processes" IOSR Journal of Engineering (IOSRJEN), Volume 2, Issue 9 [September 2012].

[4] Dr.K.M.Kenchireddy, Dr.C.T.Jayadeva and Mr.Yathiraj.K "Wear Behaviour Of Hard facing Deposits On Mild Steel" Global Journal Of Engineering Science And Researches [Aug 2014]. [4]

[5] K.M. KenchiReddy and C.T. Jayadeva "The Effect of Microstructure on 3 Body Abrasive Wear Behavior of Hard facing Alloys" Bonfring International Journal of Industrial Engineering and Management Science, Vol. 4, No. 1 [February 2014]. [5]

[6] Anand Sagar, Dr.G.K.Purohit "Some Studies on Mig Hard facing Of Mild Steel Components" International Journal of Engineering Research and Development Volume 4, Issue 8 [November 2012]. [6]

[7] G.R.C.Pradeep, A.Ramesh, B. Durga Prasad "A Review Paper On Hard facing Processes And Materials" International Journal of Engineering Science and Technology Vol. 2(11), 2010. [7]

[8] Mr. Vikas Kamboj, Er. Brij Bhushan, Dr. Abhishek Kamboj "Optimization Of Process Parameters And Study Of Hardness During Hard Facing Of Mild Steel Using Taguchi Method" International Journal Of Engineering Sciences \& Research Technology. June 2015. [8]

[9] Harvinder Singh "Studies the Effect of Iron Based Hard facing Electrodes on Stainless Steel Properties Using Shielded Metal Arc Welding Process" International Journal of Research in Advent Technology, Vol.2, No.4, April 2014. [9] 